\title{
Explaining sustainable regional integration to my parents
}

\author{
Zenyram Koff Maganda
}

I have been immersed in sustainable development and regional integration since I was a baby through the activities of the RISC Consortium. I have met people coming from different parts of the world to discuss their regions and how they affect communities. I have had the opportunity to travel and see how life is in different world regions, how people are the same, and how they are different. One day, my parents asked me to explain to them what "sustainable regional integration" means. This is my answer.

As an environmentalist and activist, I care deeply about sustainability because I live in green and natural areas, and I would never want to see these places disappear or be destroyed. These natural areas provide food to eat, water to drink, and air to breath, among other benefits, such as life and peaceful surroundings.

I am the founder of Custodios niños, niñas y adolescentes, a youth group of environmentalists. This group has been active since the winter of 2017. We visit the natural protected areas of Xalapa, Mexico, and we also clean them of plastics and other garbage when possible. We also had two group visits to local radio shows in which we presented our vision of environmental consciousness and our activities. For example, we recently started a project where we talk to local business owners, specifically in the food industry, about packaging. We want them to use minimal packaging and promote the re-use of containers and mugs/bottles for drinks among their clients. Our main focus is to protect the natural protected areas of Xalapa and to make our voices as environmentally conscious kids and teens heard (Ayora, 2020).

As a young person, I care about the Brundtland report's definition of sustainable development: "development that meets the needs of the present without compromising the ability of future generations to meet their own needs" (Brundtland, 1987). Often, it seems that the youth of the world is "battling adults" on matters such as climate change because of the fear that the planet on which we live is being further destroyed. If we stay on the current track of unsustainable lifestyle habits that have 
negative impacts on natural resources, we will end up destroying an irreplaceable planet. I want a planet that is well taken care of so we can live in harmony with it. Like many in my generation, I am afraid of our current course because of the environmental problems that humanity creates. For example, there is an island of plastic bigger than the size of France in the Pacific Ocean (Evers, 2019). Also, I am afraid that our bodies of water are being destroyed. Locally, we care about the "Laguna del Castillo" being polluted and Custodios niños has begun taking action. We are taking responsibility for our planet, for ourselves, and for the future (Ayora, 2020).

Youth can promote sustainable development in many ways. I believe in creating constructive intergenerational dialogues and youth participation in political discussions, but I do not believe in getting angry at older generations or at government. The Fridays for Future movement aimed at addressing climate change is a good starting point. I am in touch with the leaders in Luxembourg. They meet weekly to talk about how to address climate change. They work with schools and are constantly creating new content for social media. They are active with different protests and information campaigns. They use social media to stay in contact, and they work a lot with teenagers. They are also in contact with politicians in Luxembourg promoting the involvement of youth in public policies. I am pleased that the youth is very much involved in the fight against climate change and in protection of the environment. The youth of today is the largest generation in history with about 2 billion people between the ages of 10 and 24 (United Nations, n.d.). If every person in that age group has sustainable habits and engages to protect the environment, we will have a good chance of fighting climate change. However, I propose a more ambitious approach.

While I appreciate this movement as an important example of youth activism, it is a specific protest. Society is the biggest threat to sustainable development because of daily habits that affect the environment that go beyond climate change. These include, among others:

- use of cars, even for short distances;

- eating out;

- constant use of plastic;

- overconsumption;

- consuming products made in sweat shops; and

- use of unsustainable packaging materials.

While protests are important, we need to propose visions for our planet and our society for the future. For example, the project "Yo dialogué con los custodios niños, niñas y adolescents" ("I dialogue with the youth custo- 
dians") is about creating a dialogue with restaurant owners listening regarding their environmental concerns and ideas for potential solutions. At the same time, the "custodios" give them suggestions on how to make their businesses more sustainable. One of our suggestions is eliminating all plastics. It is a multisectoral and transgenerational dialogue.

A good way of developing as a society without harming the environment is to propose behavioral changes in local communities such as:

- carpool rides and public transportation;

- use of bikes as transportation;

- use of reusable water bottles and lunchware at work and school;

- recycle, reduce, and reuse in general;

- cooking at home as much as possible;

- becoming Vegan/Vegetarian;

- consuming local and organic ingredients; and

- shopping in bulk.

We can support sustainability through adaptation, innovation, and invention. The youth of today can experiment with simple and advanced technology aimed at protecting the environment in addition to supporting sustainability by doing some of the actions already suggested. For example, the United Nations Environment Program sponsors the Young Champions of the Earth prize, recognizing the youth of today and their innovative actions to protect the environment. Some of the 2019 winners, such as Anna Luisa Beserra, were recognized for technological advances (her invention, Agualuz, is a devise that reduces waterborne diseases), while others, such as Adjany Costa, an activist in Angola, was recognized for promoting community-based policy change (United Nations Environment Program, 2019).

The Sustainable Development Goals (SDGs) are a good starting point for environmental action because they represent the essential needs for humanity to develop. They are all important, but the most relevant one for me is SDG 12 on responsible consumption and production because it addresses how much we consume and how much plastic we create. (Sustainable Development Goals, n.d.). Sustainable development is much more than a list of goals. I define sustainable development as the human capacity to move forward as a society without harming the environment, without exploiting natural resources; living in harmony with our planet.

In order to achieve sustainability, we need to form dialogues between government, communities, business owners, and youth. Involving youth is important since young people are making their voices heard in communities, businesses, and governments in many ways. A good example 
of this is ten-year-old Ryan Hickman, who is active in recycling (Peled, 2018). Hickman has convinced most of his community in Orange County, California, to recycle. He goes to different places, such as golf courses, to get all their garbage; he separates it, and then takes it to the recycling center. He has a company called Ryan's Recycling Company. They are constantly having people recycle. Ryan goes with his father to clean the beach. He also volunteers with the Pacific Marine Mammal Center (CNN young wonders, 2017, n.d.). This company illustrates how effective modern sustainability approaches can succeed through community action.

Governments could address sustainable development by building communities with modern systems that go hand in hand with sustainability. New transport policies in many European cities have both adopted environmentally friendly buses and trams and built bicycle lanes on most major urban roads. For example, Luxembourg has established the vel'OH program where riders can rent bicycles from different stations placed throughout the city (Ville de Luxembourg, n.d.). Also, many municipalities in Luxembourg, such as Hesperange, provide a similar service for electric car rental and recharge (Hesperange, n.d.).

My hope is that governments could further put the authority they have to good use by creating a dialogue with young people centered on sustainable development. A general sustainability approach to education would teach children about the environmental consequences of their daily actions and promote more sustainable behaviors following the examples previously mentioned. Children could then pass this knowledge on to their families, thereby increasing its impact.

I have been fortunate to live these experiences. In second grade, I attended Bios-Lila Montessori, which is a sustainable school in Coatepec, Mexico. All buildings were built by hand with eco-friendly materials. As students, we visited a working farm once a month to learn about sustainable agriculture. I then studied at the Tlalnecapam School in Coatepec where we had a working vegetable garden and compost systems for which the students were responsible. The curriculum was based on a sustainability philosophy. In middle school, I have studied at the OTR (Over the Rainbow) School in Luxembourg, which has recently joined the International Baccalaureate.

I am studying the Middle Years Program, which includes a Service in Action class. Through this course, students complete activities that benefit their communities and beyond in the case of more international initiatives. The key is the social-environmental component of the work that students do. All of these programs are great examples of sustainability-based education. But they are all conducted in private schools. Public education should follow these examples and more thoroughly teach about sustain- 
ability and promote social action. All schools should better incorporate parents in sustainability dialogues with students and teachers.

Government should also open direct communication channels with youth on sustainable development to involve their suggestions in public policies. For example, Ireland organized a 2019 Youth Assembly on Climate in order to address the impacts of climate change in the country and necessary actions to respond to it. Many European countries, like Luxembourg, have National Youth Assemblies and National Youth Councils where young people can make their political concerns heard. The European Union promotes the European Youth Parliament, which aims to empower young Europeans to be open-minded, tolerant, and active citizens.

One area where more youth involvement is necessary is regional integration. A region can be a space inside a country, a country itself, or a territory including multiple countries that is characterized by different kinds of interactions. The common definition of regions focuses on markets (e.g., in North America) or governments (e.g., the European Union). For me a region is more than a territory. It involves exchanges of people and much more. In my eyes, there are many kinds of regions which can be: economic, cultural, linguistic, historical, territorial, gastronomic, and even eco-systemic involving flora, fauna, and weather.

Given the variety of regions that exist, it is a challenge to combine regional integration with sustainable development, for young people and adults, especially because I cannot cite any example of a fully sustainable region. I am not sure that we really know what this means. I know a few European countries that are on their way to sustainability, which include: Luxembourg, Germany, Belgium, the Netherlands, and Finland. I have visited these countries, and they look clean and organized. When I walk through their cities, I see that they have sustainable technologies for transportation, little use of plastic bags and straws, and more recycling and reused materials. Some of them even have smart eco-buildings. The people also seem happy, and they respect the organization of the city (personal observation). For example, residents of Luxembourg separate their garbage into four or five kinds, placing each kind in a separate bin. They also respect the recycling pick-up schedule given to them by local governments. While these examples of sustainable practices are interesting, this does not necessarily mean that Europe is a sustainable region.

We do, however, have examples of unsustainable regions. One example is the North American Free Trade Agreement (NAFTA), which promoted maquiladoras along the Mexico-US border. These factories cannot be compared to the previously mentioned eco-buildings, and they have employed many women, providing low pay and difficult working conditions. Most importantly, the social conditions in the border cities in 
Mexico in which many of these women live make them vulnerable to violence. In 2014, I met Evangelina Arce, whose daughter Silvia disappeared in Ciudad Juarez in 1998. This meeting sadly taught me that there are regions where many women are exposed to violence and insecurity with bad working environments and low salaries.

Coming back to Europe, this region is meant to be more united in its approach to sustainability. During "normal" times, the European Union member states do cooperate more with each other, but the COVID-19 crisis has shown the limits of this cooperation. For example, the EU member states recently approved $€ 279$ million in EU aid following the 2019 extreme weather events in Austria, Italy, Portugal, and Spain (Europarliament, 2020). This money came from the so-called EU Solidarity Fund. In 2020, political divisions have prevented the EU from agreeing on COVID19 disaster relief, thereby pitting the EU's four largest economies-Germany, France, Italy, and Spain - against the group of countries known as the "frugal four": Austria, the Netherlands, Sweden, and Denmark (McCaffrey, 2020). The first group of countries wishes to approve 750 billion euros in cash transfers to member states affected by COVID-19. The second group does not wish to provide transfers but insists on loans, limiting the amount of regional solidarity in financial terms.

The lack of a unified COVID-19 response in the EU, and the negative social and environmental impacts of regional integration in North America have impacted communities on both continents. For this reason, a new model of regional integration is needed that focuses on the integration of people more than markets. Youth can play a role in this. In both Europe and North America, there are examples of youth movements that are regional. The Youth for Climate and Fridays for Future movements are regional, and they bring young people together incredibly well around sustainable development themes. In North America, youth movements exist as well. For example, the International Youth Foundation, "connects young people with opportunities to transform their lives. Our holistic, systems-based approach emphasizes life skills in combination with a mix of technical, vocational, and entrepreneurship training. As a result, young people are prepared to enter the workforce, create their own opportunities, and be agents of change in their communities" (International Youth Foundation, n.d.).

A sustainable region is the combination of these two visions: a region established by cooperation among people (especially youth) working to change habits and engage governments in partnerships that promote development that benefits communities without exploiting natural resources or harming the environment. I hope that when I am an adult, I can see humans and nature living in greater harmony through this vision of sustainable regional integration. 
ZENYRAM KOFF MAGANDA is currently entering eighth grade, and she attends school in both Mexico and Luxembourg. Born in Luxembourg, Koff Maganda is an international Mexican and American involved in environmental movements, and she supports different kinds of activism. She finds that the opinions of young people are often neglected in environmental discussions, so she works to make them heard because youth represent both the present and the future. Koff Maganda loves to see, taste, and try new things, walk in and enjoy natural areas, cook, bake, dance, and design. Her dream is to see a plastic-free world and a unified society where the voices of young people are heard. E-mail: kmaganda@pt.lu

\section{REFERENCES}

Ayora, G. (2020). Aprendizajes colectivos para la participación infantil en la defensa del territorio: La experiencia de las niñas y niños Custodios del Archipiélogo en mar abierto. Revista digital de divulgación científica, Sociogénesis 3(3). https://www.uv.mx/sociogenesis/debate-interdisciplinario/aprendizajes-col ectivos-para-la-participacion-infantil-en-la-defensa-del-territorio/.

Brundtland, G. (1987). Report of the World Commission on Environment and Development: Our common future. United Nations General Assembly document A/42/427.

CNN Young Wonder: Ryan Hickman. (2017, December 16). CNN. http://edition .cnn.com/videos/living/2017/12/15/cnnheroes-hickman-young-wonder-orig .cnn/video/playlists/2017-top-10-cnn-heroes/.

Europarliament. (2020, May 28). Austria, Italy, Portugal, Spain receive $€ 279 \mathrm{~m}$ after natural disasters in 2019. Europarliament News. https://www.europarl .europa.eu/news/en/press-room/20200520IPR79528/austria-italy-portugalspain-receive-EU279m-after-natural-disasters-in-2019.

Evers, J. (2019). Great Pacific Garbage Patch. National Geographic Resource Library. https://www.nationalgeographic.org/encyclopedia/great-pacific-garbagepatch/.

Hesperange. (n.d.) Le service de mobilité électrique. Retrieved July 10, 2020, from https://www.hesperange.lu/fr/Documents/Ecologie/Explications.pdf.

Hickman, R. (n.d.) Ryan's Recycling Company. Retrieved July 15, 2020, from https:// ryansrecycling.com/.

International Youth Foundation. (n.d.). What we do. Retrieved July 8, 2020, from https://www.iyfnet.org/what-we-do.

McCaffrey, D. (2020, June 18). No breakthrough as EU divisions remain over $€ 750$ bn COVID-19 recovery plan. Euronews. https://www.euronews.com/2020/06/18/ will-european-leaders-agree-a-covid-19-recovery-plan-on-friday.

Peled, S. (2018, January 15). At 7, this boy runs a company and saves for college. CNN. https://edition.cnn.com/2017/03/09/us/recycling-boy-trnd/index.html.

Sustainable development goals. (n.d.). Sustainable Development Knowledge Platform. United Nations. Retrieved from http://sustainabledevelopment.un .org/?menu=1300. 
United Nations. (n.d.). Youth and the SDGs. Sustainable Development Goals. Retrieved July 8, 2020, from http://www.un.org/sustainabledevelopment/youth/. United Nations Environment Program. (2019). Meet our winners. Young Champions of the Earth-UN Environment Program. Retrieved from http://www.unen vironment.org/youngchampions/winners.

Ville de Luxembourg. (n.d.). Vel'OH!. Retrieved July 10, 2020, from https://www .vdl.lu/en/getting-around/bike-or-foot/bike-rental-and-other-services/veloh. 